\title{
Relations between bacterial nitrogen metabolism and growth efficiency in an estuarine and an open-water ecosystem
}

\author{
Niels O. G. Jørgensen ${ }^{1, *}$, Niels Kroer ${ }^{2}$, Richard B. Coffin ${ }^{3, * *}$, Matthew P. Hoch $^{3, * * *}$ \\ ${ }^{1}$ Department of Ecology, Royal Veterinary and Agricultural University, Thorvaldsensvej 40, \\ DK-1871 Frederiksberg C, Denmark \\ ${ }^{2}$ Department of Marine Ecology and Microbiology, National Environmental Research Institute, Frederiksborgvej 399, \\ DK-4000 Roskilde, Denmark \\ ${ }^{3}$ United States Environmental Protection Agency, Gulf Ecology Division, One Sabine Island Drive, Gulf Breeze, \\ Florida 32561, USA
}

\begin{abstract}
Bacterial uptake or release of dissolved nitrogen compounds (amino nitrogen, urea, ammonium and nitrate) were examined in $0.8 \mu \mathrm{m}$ filtered water from an estuary (Santa Rosa Sound [SRS], northwestern Florida) and an open-water location in the Gulf of Mexico (GM). The bacterial nutrient dynamics were related to oxygen consumption and activity of enzymes involved in nitrogen assimilation (glutamate dehydrogenase [GDH], glutamine synthetase [GS] and aminopeptidase activity [leu-MCA]). Dissolved free amino acids (DFAA) were the dominant $\mathrm{N}$ source to the bacteria, followed by dissolved combined amino acids (DCAA), ammonium and nitrate. Nitrogen budgets of the bacteria (assimilation of $\mathrm{N}$ compounds relative to accumulated $\mathrm{N}$ biomass) demonstrated that, except for the initial $24 \mathrm{~h}$ period in the GM cultures, the assimilated $\mathrm{N}$ compounds sustained all of the bacterial $\mathrm{N}$ demand. Urea was released in both sets of cultures, but in the SRS cultures the produced urea was reassimilated. Major differences in the bacterial $N$ metabolism between the open-water GM and the estuarine SRS stations were observed. Relative to the GM station, bacteria in the SRS cultures had (1) a 2.4 to $18 \times$ higher cell-specific DFAA assimilation, (2) a $2.5 \times$ higher cell-specific leu-MCA activity, (3) a 3 to $10 \times$ higher GDH:GS activity ratio and (4) a 1.9 to $4.1 \times$ lower cell-specific respiration. The larger nutrient availability at the estuarine station probably caused these differences in uptake and metabolism of nitrogen as well as the lower respiratory rate, relative to the open-water station. Therefore, we hypothesize that availability of nitrogen, rather than carbon, controlled the bacterial activity in the cultures. Our results suggest that bacteria in eutrophic conditions can be more important mediators of nitrogen than those in oligotrophic conditions, in which bacteria temporarily may immobilize labile nitrogen.
\end{abstract}

KEY WORDS: Nitrogen metabolism - Growth efficiency - Amino acids - Urea - Inorganic nitrogen · Enzyme activity $\cdot$ Gulf of Mexico

\section{INTRODUCTION}

The amount and composition of dissolved organic matter (DOM, typically measured as dissolved organic carbon $[\mathrm{DOC}]$ ) in pelagic environments control the

•E-mail: nogj@kvl.dk

Present addresses:

- Environmental Quality Sciences Section, Code 6115, Naval Research Laboratory, 4555 Overlook Dr., SW, Washington, DC 20375, USA

-.Biology Department, Environmental Science Building, Malaspina University-College, 900 Fifth Street, Nanaimo, British Columbia V9R 5S5, Canada capacity for growth of heterotrophic bacteria. The fraction of the DOM pool that may support bacterial production is variable, but the relative amount of bacterially labile DOC increases with the amount of DOC (review of 36 marine locations by Søndergaard \& Middelboe 1995j. Since the concentration of DOC typically is higher in estuarine than in oligotrophic waters (Happ et al. 1977, Coffin et a1. 1993, Guo et al. 1996), relatively higher bacterial production can therefore be expected in the eutrophic conditions. However, although labile carbon in some studies has been found to be the limiting factor for bacterial growth (Kirchman et al. 1989, Carlson \& Ducklow 1996), availability of 
nutrients ( $\mathrm{N}$ and $\mathrm{P}$ ) may also limit the potential for bacterial production (Kroer 1993, Zweifel et al, 1993, Cotner et al. 1994).

The trophic status of an environment generally does not determine whether the bacterial production is controlled by $\mathrm{N}$ or $\mathrm{P}$ (inorganic as well as organic), or $\mathrm{C}$. In the oligotrophic ocean, low concentrations of inorganic nutrients prevail, but studies indicate that $C$ rather than $N$ and $P$ may limit the bacterial production in these environments, perhaps due to low primary production (Carlson \& Ducklow 1996, Cherrier et al. 1996). In more eutrophic conditions, autochthonous nutrient cycling and input of allochthonous matter influence whether $\mathrm{C}, \mathrm{N}$ or $\mathrm{P}$ limits bacterial growth. Batch culture studies of bacteria from eutrophic waters indicate that carbon as well as inorganic nutrients can control the production of bacteria in these locations (Jørgensen et al. 1993, Zweifel et al. 1995).

The lability of DOC may not only control the total bacterial production but may also influence the proportion of active bacteria in the microbial community. In sea waters of increasing DOC concentration, the percentage of active bacteria was found to increase with the DOC pool, and active bacteria were 3 -fold more abundant in estuarine than in true marine environments (del Giorgio \& Scarborough 1995). The higher lability of DOC and the increased proportion of active bacteria in estuarine and high-DOC waters suggest that these locations provide bacteria with more favorable nutrient conditions than do oligotrophic waters.

Dominant labile DOM compounds utilized by pelagic bacteria include dissolved free and combined amino acids (DFAA and DCAA) that may support a substantial portion of the $\mathrm{C}$ and $\mathrm{N}$ demand (Coffin 1989, Fuhrman 1990, Hoch \& Kirchman 1995, Middelboe et al. 1995), and, especially in oceans, free monosaccharides (Billen et al. 1980, Rich et al. 1996). The coincidence of a small pool of labile DOM and low uptake of amino acids in open waters, relative to estuaries (Keil \& Kirchman 1991), may indicate that amino acids make up a higher proportion of the labile DOM pool in estuaries than in open water.

A high lability of estuarine DOC might be expected to influence the bacterial growth yield (cell production relative to DOC consumption), which could explain a higher bacterial production in estuaries, relative to more oligotrophic waters. However, according to the literature, variable bacterial growth yields have been found in comparable environments (Jahnke \& Craven 1995). The variability can be exemplified by data from Coffin et al. (1993), who found bacterial growth yields of 0.4 to $35 \%$ during a seasonal study of a shallow marine station, but values of 37 to $79 \%$ in a mesocosm study of the same location. In oceanic waters, growth yields usually are lower, ranging down to $0.8 \%$ (Cherrier et al. 1996). These variations probably reflect differences in substrate quality and quantity, e.g. of labile DOM and inorganic nutrients, but in addition the growth rate may influence the growth yield. Thus, Middelboe et al. (1992) observed a correlation between generation time and growth yield of natural marine bacteria (a long generation time coincided with a low growth yield, and vice versa).

The objective of the present study was to examine if bacterial nitrogen metabolism and carbon growth yield in an estuarine and an open-water location is regulated by location-specific nutrient parameters. The nitrogen metabolism was determined from net fluxes of DFAA, DCAA and inorganic nitrogen (ammonium, nitrate and urea). In addition, the activity of enzymes involved in the intracellular nitrogen assimilation (glutamate dehydrogenate [GDH] and glutamine synthetase [GS]) was measured. The expression of either enzyme is controlled by the availability of nitrogen to the bacteria. GDH and GS are stimulated when the intracellular ammonium level is high and low, respectively (Moran et al. 1994). Our results demonstrate that relative to the open-water location, bacteria from the estuary had a higher growth yield, had a larger cellspecific uptake of amino acids, had higher relative GDH enzyme activity, and exhibited a temporary release of superfluous nitrogen as urea. Since bacteria from the 2 locations had a different nitrogen metabolism, we hypothesize that availability of nitrogen, rather than carbon, controlled the bacterial activity in the cultures.

\section{MATERIALS AND METHODS}

Sampling and experimental set-up. Seawater was collected at $1 \mathrm{~m}$ depth at Sabine Island in Santa Rosa Sound (SRS), Pensacola, Florida, and at $10 \mathrm{~m}$ depth in the Gulf of Mexico (GM) (30 03.46 N, $\left.88^{\circ} 07.54^{\prime} \mathrm{W}\right)$, about 65 miles $(\sim 105 \mathrm{~km})$ south of Mobile, Alabama, from OSV 'Peter W. Anderson'. Salinities and water temperatures were $26 \%$ and $22.5^{\circ} \mathrm{C}$, and $33.1 \%$ and $25.0^{\circ} \mathrm{C}$, in SRS and GM, respectively. SRS is a shallow and moderately eutrophic estuary, while the nutrient regime at the sampling station in the GM is oligotrophic (Lohrenz et al. 1990). At both sampling stations, $40 \mathrm{l}$ of $0.8 \mu \mathrm{m}$ filtered seawater (Millipore, Bedford, USA) was prepared for batch culture experiments in triplicate 501 acid-rinsed polyethylene carboys (Nalge Nunc International, Rochester, USA). The cultures were covered with dark foil and incubated close to in situ temperature for $72 \mathrm{~h}$.

At various time points during the incubations, subsamples were taken for (1) chemical analysis of DFAA, 
DCAA, nitrate, ammonium and urea, (2) measurements of particulate organic carbon and nitrogen (POC and PON) and bacterial counts, and (3) measurements of bacterial activity (oxygen consumption, DFAA assimilation, aminopeptidase and nitrogen enzyme activities).

Chemical analysis. Concentrations of DFAA were measured by HPLC after precolumn derivatization with o-phthaldialdehyde (Lindroth \& Mopper 1979, Jørgensen et al. 1993). For analysis of DCAA, triplicate water samples were hydrolyzed by a microwave technique (Jørgensen \& Jensen 1997). After hydrolysis, the total amounts of DCAA were determined from the composition of the individual amino acids by HPLC as described above. Concentrations of DFAA were subtracted from the total amino acids pool for calculation of DCAA concentrations.

Nitrate and ammonium were measured in triplicates by standard autoanalyzer procedures. Concentrations of urea were determined by the diacetyl monoxime method (Price \& Harrison 1987). The sensitivity of the procedure was improved by an immediate cooling of the samples after the color reaction, as recommended by Mulvenna \& Savidge (1992).

Concentrations of dissolved monosaccharides and total carbohydrates were measured using the 3methyl-2-benzothiazolinone hydrazone hypochloride (MBTH) by Johnson \& Sieburth (1977), with the modifications of Pakulski \& Benner (1992). No samples for analysis of saccharides at $72 \mathrm{~h}$ were available.

Biomass estimates. For POC and PON analysis, 200 to $300 \mathrm{ml}$ water was filtered through pre-ashed $13 \mathrm{~mm}$ GF/F filters (Whatman International, Maidstone, UK). The filters were kept dry in a heated vacuum desiccator at $45^{\circ} \mathrm{C}$ until assayed in a Carlo Erba NA $1500 \mathrm{CHN}$ analyser (Carlo Erba Instruments, Milan, Italy). The POC and PON values were corrected for $\mathrm{C}$ and $\mathrm{N}$ on blank filters and for adsorption of DOC to the filters by filtration of $0.2 \mu \mathrm{m}$ filtered water through blank $\mathrm{GF} / \mathrm{F}$ filters. Filtrates of the PON and POC analyses were used for analysis of dissolved amino acids, ammonium, nitrate and urea. Invalid analysis of PON in some of the samples was corrected for by calculating PON from POC values, assuming a bacterial C/N ratio of 5 (Kroer 1994).

Bacterial abundance was determined in Lugol-preserved samples by staining with DAPI (concentration $10 \mathrm{mg} \mathrm{l}^{-1}$ ) for about $10 \mathrm{~min}$ (Porter \& Feig 1980). The bacterial samples were filtered onto black $0.2 \mu \mathrm{m}$ pore size polycarbonate filters (Poretics Corp., Livermore, USA) and enumerated with a Zeiss Axioplan epifluorescence microscope (Zeiss, Göttingen, Germany).

Oxygen measurements. At start of the experiments, 30 gas tight bottles $(25 \mathrm{ml})$ were filled with water from each of the carboys and incubated in the dark at in situ temperature. Dissolved oxygen in the bottles was mea- sured at regular intervals by an automatic potentiometric titration (Coffin et al. 1993). Bacterial oxygen consumption was determined on the basis of the decrease in the concentration of dissolved oxygen in the bottles. The gross growth efficiency (GE) was calculated according to the equation: $\mathrm{GE}=\mathrm{POC} /(\mathrm{POC}+$ oxygen consumption) $\times 100$, assuming a respiratory quotient of 1

DFAA assimilation. Incorporation of free amino acids was determined from addition of $9 \mathrm{nCi}$ of an equimolar mixture of the following $L-\left[{ }^{14} \mathrm{C}(\mathrm{U})\right]$ amino acids: ala, arg, asp, glu, gly, his, ile, leu, lys, phe, pro, ser, thr, tyr and val (ICN Biochemicals, Costa Mesa, USA) to triplicate $20 \mathrm{ml}$ water samples. One of the samples was a control with $2 \%$ final concentration of buffered $\left(\mathrm{pH}\right.$ 8) formaldehyde. Addition of the ${ }^{14} \mathrm{C}$ amino acids increased the natural DFAA concentration by a maximum of $2 \mathrm{nM}$ (typically less than $2 \%$ of the original DFAA concentration). The samples were incubated at 23 to $25^{\circ} \mathrm{C}$ for 10 to $120 \mathrm{~min}$ to obtain a maximum isotope uptake of about $10 \%$. The incubations were stopped by addition of buffered formaldehyde. The water samples were filtered through $0.2 \mu \mathrm{m}$ pore size membrane filters (MFS, Pleasanton, USA), followed by rinsing with particle-free seawater. The filters were radioassayed by liquid scintillation counting. For calculation of the total DFAA flux, assimilation of the 15 amino acids was assumed to represent assimilation of the natural DFAA.

Aminopeptidase assay. Aminopeptidase activity was measured by adding the substrate analog leucineMCA (leucine-4-methyl-7-coumarinylamide) to quadruple $2 \mathrm{ml}$ subsamples in clear $4 \mathrm{ml} 4$-way plastic cuvettes. The final concentration of leucine-MCA was $4 \mu \mathrm{M}$. The samples were incubated for 2.5 to $6 \mathrm{~h}$. Fluorescence was measured on a LS50 Perkin-Elmer spectrofluorometer (The Perkin-Elmer Company, Norwalk, USA) at $380 \mathrm{~nm}$ excitation and $440 \mathrm{~nm}$ emission wavelengths with a 3 s integration time. AMC (7-amido-4-methycoumarin) standards (the compound formed after cleavage of the leucine-MCA bond) of 0 to $10 \mu \mathrm{M}$ were used for calibration of the spectrofluorometer.

Nitrogen enzyme assays. GS activity was assayed by the $\gamma$-glutamyl transferase (GT) reaction (Shapiro \& Stadtman 1970, Bender et al. 1977), which estimates total enzyme activity regardless of subunit adenylation state $\left(\mathrm{Mn}^{2+}\right.$ dependent activity). GDH activity was measured by the fluorometric detection of nicotinamide adenine dinucleotide (phosphate) $\left[\mathrm{NAD}(\mathrm{P})^{+}\right]$ (Ahmed et al. 1977).

Bacteria for assays were collected by filtration through tandem filtration cartridges equipped with a $10 \mu \mathrm{m}$ and a $0.8 \mu \mathrm{m}$ filter unit, arranged in series (Nuclepore, Cambridge, USA). Bacterial biomass in 0.2 to $1.0 \mathrm{l}$ of $0.8 \mu \mathrm{m}$ size-fractionated seawater was col- 
lected on $0.45 \mu \mathrm{m}$ Millipore HA (SRS) or $0.22 \mu \mathrm{m}$ Millipore GS membranes (GM). Triplicate filters were immediately transferred to $2 \mathrm{ml}$ tubes with $0.5 \mathrm{~g}$ of $0.1 \mathrm{~mm}$ diameter zorconium beads and $1 \mathrm{ml}$ of ice-cold buffered assay mixture (without the reaction limiting substrate). The tubes were beaten in a Mini-Bead Beater (Biospec Products Inc., Bartlesville, USA) for $2 \mathrm{~min}$, followed by chilling on ice. Membranes were then made permeable to the reactants using $0.01 \%$ $(\mathrm{w} / \mathrm{v})$ cetyltriammonium bromide (CTAB) (Bender et al. 1977) for $5 \mathrm{~min}$ at room temperature. Addition of CTAB prior to bead beating resulted in excessive foaming of the sample.

Reactions were started by the addition of substrates and followed by incubation at $30^{\circ} \mathrm{C}$ for 0.5 to $2 \mathrm{~h}$. Linearity of product formation within $2 \mathrm{~h}$ incubations has been determined for bacterioplankton from a variety of marine environments. Reactions were stopped by acidification with GT 'stop-mix' for GS assays (Bender et ai. 1977 ) and $0.1 \mathrm{~N} \mathrm{HCl}$ for the GDH assays (Ahmed et al. 1977). The concentration of $\gamma$-glutamyl hydroxamate $(\mathrm{GH})$ in GS assays was determined at $540 \mathrm{~nm}$ absorp- tion immediately after centrifuging precipitates and filter material. The GDH assays were frozen on dry ice and stored at $-20^{\circ} \mathrm{C}$ until the $\mathrm{H}_{2} \mathrm{O}_{2}$ derivative of $\mathrm{NAD}(\mathrm{P})^{+}$could be determined by fluorescence (Ahmed et al. 1977). Enzyme specific activity was defined as the GS units per bacterial abundance in the $<0.8 \mu \mathrm{m}$ size fraction. GS units were defined as $\mu \mathrm{mol} \mathrm{GH}$ produced per hour, and GDH units were defined as $\mu \mathrm{mol}$ $\mathrm{NAD}(\mathrm{P}) \mathrm{H}$ oxidized per hour.

Statistical tests. Comparisons of cultures and treatments were done by $t$-tests, if no other information is given (SigmaStat; Jandel Scientific, San Rafael, USA).

\section{RESULTS}

\section{Bacterial production and nutrient dynamics}

\section{Gulf of Mexico}

The bacterial density increased from 1.5 to $3.0 \times 10^{6}$ cells $\mathrm{ml}^{-1}$ during the $72 \mathrm{~h}$ incubation period, with a
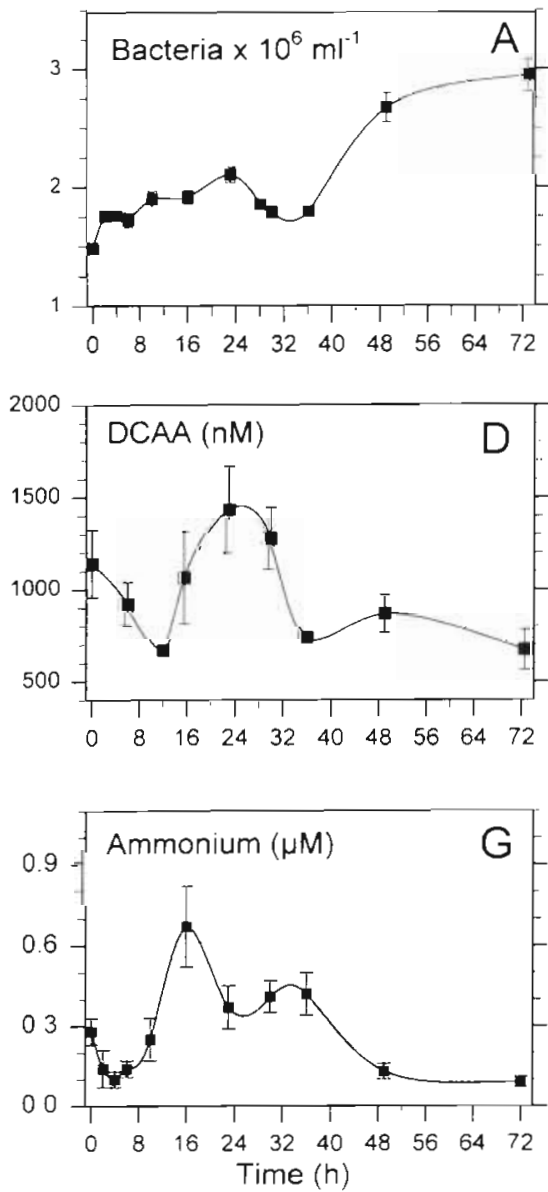
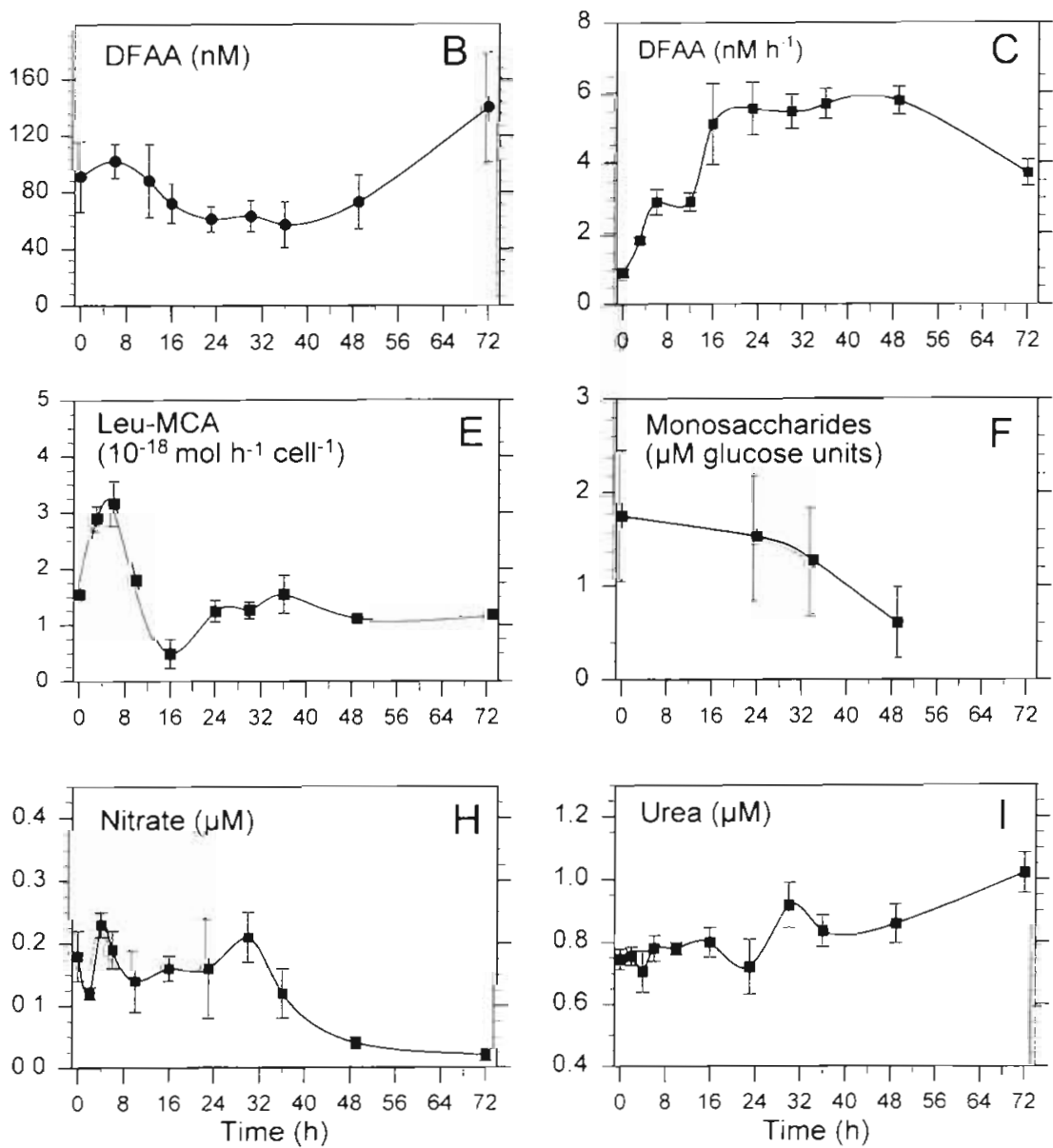

Fig. 1. Gulf of Mexico batch cultures. Bacterial abundance and activity, and concentrations of nutrients in triplicate cultures. Means \pm 1 SD shown ( $n=6$ or 9 [urea]) 
decline to $1.8 \times 10^{6}$ cells $\mathrm{ml}^{-1}$ between 28 and $36 \mathrm{~h}$ (Fig. 1A). The concentration of DFAA was reduced from 100 to $60 \mathrm{nM}$ within the first half of the incubation period, but increased to about $140 \mathrm{nM}$ at $72 \mathrm{~h}$ (Fig. 1B). The DFAA assimilation raised significantly to a plateau of 5 to $6 \mathrm{nM} \mathrm{h}^{-1}$ after $16 \mathrm{~h}$, but after $48 \mathrm{~h}$ the assimilation was reduced (Fig. 1C).

The occurrence of DCAA was reduced initially from 1140 to $670 \mathrm{nM}$, after which the concentration peaked at $1435 \mathrm{nM}$ after $23 \mathrm{~h}$ (Fig. 1D). At $72 \mathrm{~h}$, when maximum bacterial abundance was observed, the DCAA concentration had declined to $675 \mathrm{nM}$. The variable DCAA pool indicated that assimilation as well as release of DCAA occurred in the cultures. The cellspecific aminopeptidase (leu-MCA) activity doubled during the initial $6 \mathrm{~h}$, followed by a decrease to a level of 1 to $1.5 \times 10^{-18} \mathrm{~mol} \mathrm{~h}^{-1}$ cell $^{-1}$ after $24 \mathrm{~h}$ (Fig. $1 \mathrm{E}$ ). No correlations between changes in DCAA and peptidase activity were obvious ( $\mathrm{p}<0.05$, paired $t$-test).

The concentration of dissolved monosaccharides was reduced from $1.8 \mu \mathrm{M}$ at the start of the incubations, to $0.6 \mu \mathrm{M}$ at $49 \mathrm{~h}(\mathrm{p}<0.05)$ (Fig. 1F). Total dissolved car- bohydrates varied between 3.1 and $5.8 \mu \mathrm{M}$, but no trends were obvious (data not shown).

The concentration of ammonium in the cultures peaked at $16 \mathrm{~h}$, after which it decreased to $0.1 \mu \mathrm{M}$ at $72 \mathrm{~h}$ (Fig. 1G). Nitrate varied between 0.10 and $0.25 \mu \mathrm{M}$ for the first $32 \mathrm{~h}$, but declined to below $0.02 \mu \mathrm{M}$ by $72 \mathrm{~h}$ (Fig. $1 \mathrm{H}$ ). Urea was released during the incubation, leading to a concentration increase from initially $0.75 \mu \mathrm{M}$, to $1.0 \mu \mathrm{M}$ at $72 \mathrm{~h}$ (Fig. 1I).

\section{Santa Rosa Sound}

The bacterial density increased from initially $2.2 \times$ $10^{6} \mathrm{ml}^{-1}$ to $3.9 \times 10^{6} \mathrm{ml}^{-1}$ at $72 \mathrm{~h}$, with an intermediate peak of $3.7 \times 10^{6} \mathrm{ml}^{-1}$ at $18 \mathrm{~h}$ (Fig. $2 \mathrm{~A}$ ).

At start of the experiment, concentrations of DFAA were about $180 \mathrm{nM}$, but the bacterial uptake reduced the concentrations to $60 \mathrm{nM}$ at $72 \mathrm{~h}$ (Fig. 2B). Assimilation of DFAA fluctuated between 12 and $29 \mathrm{nM} \mathrm{h}^{-1}$, with peaks at 4 and $30 \mathrm{~h}$ (Fig. 2C). DCAA varied from $975 \mathrm{nM}$ at the start to $735 \mathrm{nM}$ at $72 \mathrm{~h}$ (Fig. 2D). The
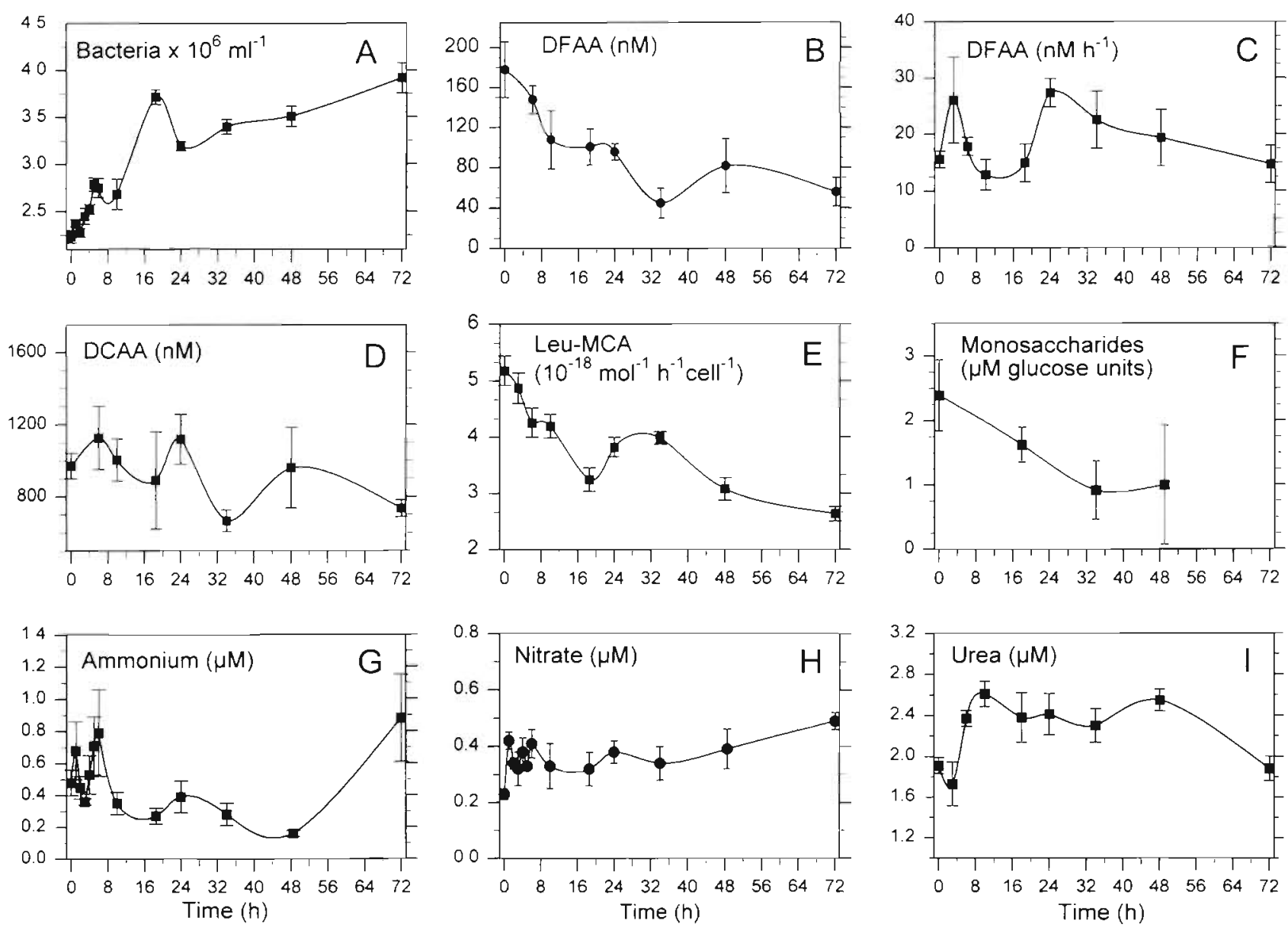

Fig. 2. Santa Rosa Sound batch cultures. Bacterial abundance and activity, and concentrations of nutrients in triplicate cultures. Means \pm 1 SD shown $(n=6$ or 9 [urea]) 
aminopeptidase (leu-MCA) activity decreased from 5.1 to $2.7 \times 10^{-18} \mathrm{~mol} \mathrm{~h}^{-1} \mathrm{cell}^{-1}$ during the experiment, with an intermediate peak of $4 \times 10^{-18} \mathrm{~mol} \mathrm{~h}^{-1}$ cell $^{-1}$ between 24 and $36 \mathrm{~h}$ (Fig. 2E).

The concentration of dissolved monosaccharides varied between 2.4 (start) and $1.1 \mu \mathrm{M}(49 \mathrm{~h})$ but changes were not statistically different $(p>0.05)$ (Fig. 2F). Concentrations of total dissolved carbohydrates ranged from 2.8 to $4.7 \mu \mathrm{M}$. No trends were found (data not shown).

The concentration of ammonium ranged from 0.35 to $0.8 \mu \mathrm{M}$ within the initial $6 \mathrm{~h}$, but increased to $0.9 \mu \mathrm{M}$ at $72 \mathrm{~h}$ after a drop to $0.15 \mu \mathrm{M}$ at $49 \mathrm{~h}$ (Fig. 2G). Nitrate fluctuated between 0.2 and $0.5 \mu \mathrm{M}$ (Fig. $2 \mathrm{H}$ ). The concentration of urea increased from $1.9 \mu \mathrm{M}$ at the start to a level of 2.4 to $2.6 \mu \mathrm{M}$ between 8 and $48 \mathrm{~h}$, after which it declined to $1.9 \mu \mathrm{M}$ (Fig. 2I).

\section{Cell-specific respiration and DFAA assimilation}

To determine the cell-specific respiration and DFAA assimilation rates, oxygen consumption and DFAA assimilation were related to the increase in bacterial numbers. Two time segments of actively dividing cells (based on increase in cell numbers) as well as the total incubation period were included. The periods of actively growing cells were (1) 0 to $24 \mathrm{~h}$ and (2) 36 to $49 \mathrm{~h}$ for the GM cultures, and (1) 0 to $18 \mathrm{~h}$ and (2) 36 to $49 \mathrm{~h}$ for the SRS cultures. A temporary reduction in bacterial numbers occurred in both cultures after 1 to $1 \frac{1}{2} \mathrm{~d}$ of growth.
The bacterial community in the SRS cultures generally had low respiration and high DFAA assimilation relative to the GM cultures (Table 1). The cell-specific respiration rate in the SRS cultures was 0.24 - to 0.53 -fold below that in the GM cultures $(p<0.05)$, whereas the cell-specific DFAA assimilation rate was 2.4- to 18 -fold higher. In the SRS cultures, respiration and DFAA assimilation both decreased from Period 1 to Period $2,2.2$ - and 5.8-fold higher cell-specific respiration and assimilation, respectively, was measured in the first in comparison to the second growth period. In the GM cultures, respiration remained unchanged during the 2 growth periods but DFAA assimilation was 1.3-fold higher in Period 2 than in Period 1. When comparing the 2 periods with the total incubation period, the average $72 \mathrm{~h}$ respiration and DFAA assimilation rates were intermediary or within the 2 separate periods in both the GM and SRS cultures. A tendency for a higher mean DFAA assimilation rate over the $72 \mathrm{~h}$ than within the 2 periods was found in the GM cultures (not statistically significant).

Ratios of leu-MCA activity to bacterial production, DFAA assimilation and changes in DCAA were determined in the cultures to evaluate if the DFAA assimilation influenced the leu-MCA activity, and if the leu MCA activity agreed with DCAA concentration changes. The cell-specific leu-MCA activity was rather consistent during all incubation periods, but the level was 2.5 - to 2.7 -fold higher in the SRS than in the GM cultures (Table 1). The invariable leu-MCA activity in the SRS cultures, despite a 6 -fold higher DFAA assimilation in Period 1, suggests that DFAA assimilation and

Table 1. Integrated cell-specific bacterial respiration, DFAA and DCAA assimilation, and leu-MCA activity (Means \pm 1 SD shown; variations are based on square root method). The time intervals represent periods with actively growing bacteria (determined from an increase in cell numbers) and the total $72 \mathrm{~h}$ incubation period. Numbers in parentheses are SRS rates divided by the corresponding GM rates (if statistically different [t-test, $p<0.05]$ )

\begin{tabular}{|c|c|c|c|c|c|c|}
\hline \multirow[b]{2}{*}{ Process: } & \multicolumn{3}{|c|}{ Gulf of Mexico (GM) } & \multicolumn{3}{|c|}{ Santa Rosa Sound (SRS) } \\
\hline & $0-23 \mathrm{~h}$ & $36-49 h$ & $0-72 \mathrm{~h}$ & $0-18 \mathrm{~h}$ & $36-49 h$ & $0-72 h$ \\
\hline Respiration ${ }^{\mathrm{a}}$ & $0.63 \pm 0.11$ & $0.55 \pm 0.08$ & $0.58 \pm 0.11$ & $0.28 \pm 0.05(0.44)$ & $0.13 \pm 0.05(0.24)$ & $0.25 \pm 0.06(0.53)$ \\
\hline DFAA assimilation $^{b}$ & $1.89 \pm 0.32$ & $2.52 \pm 0.27$ & $2.71 \pm 1.22$ & $34.3 \pm 5.8(18.1)$ & $6.0 \pm 0.6(2.4)$ & $11.4 \pm 3.1(4.2)$ \\
\hline Leu-MCA activity & $1.7 \pm 0.9$ & $1.3 \pm 0.3$ & $1.6 \pm 0.8$ & $4.3 \pm 0.8(2.5)$ & $3.5 \pm 0.4(2.7)$ & $3.9 \pm 0.8(2.5)$ \\
\hline $\begin{array}{l}\text { DFAA assimilation/leu- } \\
\text { MCA activity }^{d}\end{array}$ & $1.1 \pm 0.4$ & $1.9 \pm 0.5$ & $1.7 \pm 0.6$ & $7.7 \pm 1.8(7.0)$ & $1.7 \pm 0.3$ & $2.9 \pm 1.0$ \\
\hline $\begin{array}{l}\text { DCAA assimilation/leu- } \\
\text { MCA activitye }\end{array}$ & $-192 \pm 63$ & $-30 \pm 9$ & $2.8 \pm 2.0$ & $10 \pm 3$ & $354 \pm 140$ & $2.0 \pm 0.7$ \\
\hline \multicolumn{7}{|c|}{$\begin{array}{l}\text { 'Units: } 10^{-14} \mathrm{~g} \mathrm{O}_{2} \text { bacteria }{ }^{-1} \mathrm{~h}^{-1} \\
\text { bUnits: } 10^{-18} \mathrm{~mol}^{-1} \mathrm{DFAA} \text { bacteria }{ }^{-1} \mathrm{~h}^{-1} \\
\text { 'Units: } 10^{-18} \mathrm{~mol} \mathrm{~h}^{-1} \text { cell }^{-1} \\
\text { dDFAA assimilation converted to } 10^{-18} \mathrm{~mol} \mathrm{~h}^{-1} \mathrm{cell}^{-1} \text { versus leu-MCA activity } \\
\text { eDCAA assimilation (calculated from concentration changes between start and end of the periods) converted to } 10^{-18} \mathrm{~mol} \mathrm{~h}^{-1} \\
\text { cell }{ }^{-1} \text { versus leu-MCA activity }\end{array}$} \\
\hline
\end{tabular}


aminopeptidase activity (measured as hydrolysis of leucine peptide bonds) were independent processes. However, the rather constant ratio between DFAA assimilation and leu-MCA activity in the cultures (mean ratios of 1.1 to 2.9, except for SRS in Period 1) may reflect that regulation of amino acid uptake, involving both free and combined amino acids, did occur.

The ratio between DCAA concentration changes and leu-MCA activity was negative in the GM cultures in Periods 1 and 2 due to a release of DCAA, but the 0 to $72 \mathrm{~h}$ ratios suggested a positive relation between consumption of DCAA and leu-MCA activity (Table 1). In the SRS cultures, the DCAA uptake exceeded the leuMCA activity by a factor of 2 to 354 . Thus, the measured leu-MCA activity appeared not to represent the actual DCAA uptake.

\section{Bacterial carbon and nitrogen budgets}

The quantitative importance of individual substrate sources (DFAA, DCAA, ammonium, nitrate and urea) to the bacterial $\mathrm{C}$ and $\mathrm{N}$ demand was determined by relating the measured uptake of $\mathrm{C}$ and $\mathrm{N}$ to the produced POC and PON. DFAA assimilation was calculated from the net isotope incorporation (no respiration included). Utilization of DCAA, ammonium, nitrate and urea was determined from differences in concentration. For assimilation of DCAA, a respiration of $20 \%$ was assumed (Keil \& Kirchman 1992). Release of DCAA was not corrected for respiration. The calculations are based upon the 2 separate and the 0 to $72 \mathrm{~h}$ time segments previously used for calculation of the bacterial activity.

\section{Gulf of Mexico}

During Period 1 ( 0 to $24 \mathrm{~h}$ ), the growth efficiency was $17 \%$ and a negative nitrogen balance of $-56 \%$ was calculated (Fig. 3). Apparently assimilation of DFAA did not compensate for the release of DCAA and ammonium. The net amino acid release corresponded to $16 \%$ of the bacterial $\mathrm{C}$ content.

In Period 2 ( 36 to $49 \mathrm{~h}$ ), the growth efficiency had increased to $37 \%$ and the release of DCAA was comparable to the DFAA assimilation (Fig. 3). Uptake of amino acids, $\mathrm{NH}_{4}{ }^{+}$and $\mathrm{NO}_{3}{ }^{-}$met all of the bacterial $\mathrm{N}$ demand (the estimated $\mathrm{N}$ contribution was not significantly different from $100 \%$ [p $>0.05]$ ]. Amino acid carbon sustained $4.8 \%$ of the bacterial $C$ production.

When considering the entire $72 \mathrm{~h}$ period, the growth efficiency was similar to that of the 36 to $49 \mathrm{~h}$ period $(31 \%)$, but the amino acid uptake had increased to $43 \%$ of the total $\mathrm{C}$ demand. The uptake of DIN and amino $\mathrm{N}$ was sufficient to sustain the bacterial $\mathrm{N}$ production $(p<0.05)$, despite the release of urea.

\section{Santa Rosa Sound}

The bacterial growth efficiency varied from 47 to $57 \%$ during the $72 \mathrm{~h}$ period but no significant changes between the different periods were found $(p<0.05$. Fig. 3). The average $72 \mathrm{~h}$ uptake of DFAA was 5.8-fold higher than the uptake of DCAA but large variations, from 25-fold (Period 1) to 3.3-fold (Period 2), were observed (Fig. 3). Uptake of $\mathrm{N}$ from amino acids (all periods) and DIN (only Period 1) met the bacterial $N$ demand in the 3 studied periods. The $\mathrm{N}$ uptake even allowed for a net release of urea corresponding to $97 \%$ (Period 1) and 156\% (Period 2) of the nitrogen biomass. In the 0 to $72 \mathrm{~h}$ period, the only released $\mathrm{N}$ compounds were DIN, corresponding to $24 \%$ of the bacterial $N$ biomass. Amino acid $\mathrm{C}$ appeared to provide all the $\mathrm{C}$ required for the observed bacterial production during the incubation period.

\section{GDH and GS enzyme activity}

Expression of GDH and GS activity is an indicator of high and low availability of nitrogen, respectively (Moran et al. 1994). The GDH activity varied between 6 and 9 (GM cultures) and 40 and $70 \mathrm{GDH}$ units per $10^{9}$ bacteria (SRS cultures) during the $72 \mathrm{~h}$ study period (data not shown). The GS activity in the GM cultures doubled during the period and reached a level of 0.4 to 0.5 GS units per $10^{9}$ bacteria (data not shown). In the SRS cultures, the GS activity varied between 0.2 and 0.4 GS units per $10^{9}$ bacteria

The relative GDH:GS activity in GM cultures varied between 12 and 50 , with a decline at 28 h due to a low GDH activity (Fig. 4). In the SRS cultures, the relative activity decreased from initially 190 to 125 at $72 \mathrm{~h}$.

\section{DISCUSSION}

Bacterial production and metabolic activity were compared in 2 distinct ecosystems in the GM region: an estuarine and a coastal environment. Distinctions between the systems have been noted in terms of carbon sources and concentrations of organic matter and nutrients (Coffin et al. 1990, Kelley et al. 1998, Coffin \& Cifuentes unpubl. data). Stable carbon isotope analysis indicates that bacterial production in SRS is supported by a combination of organic matter from terrestrial and phytoplankton sources (Coffin et al. 1990). In comparison, the source of organic matter to bacteria in the 


\section{Gulf of Mexico}

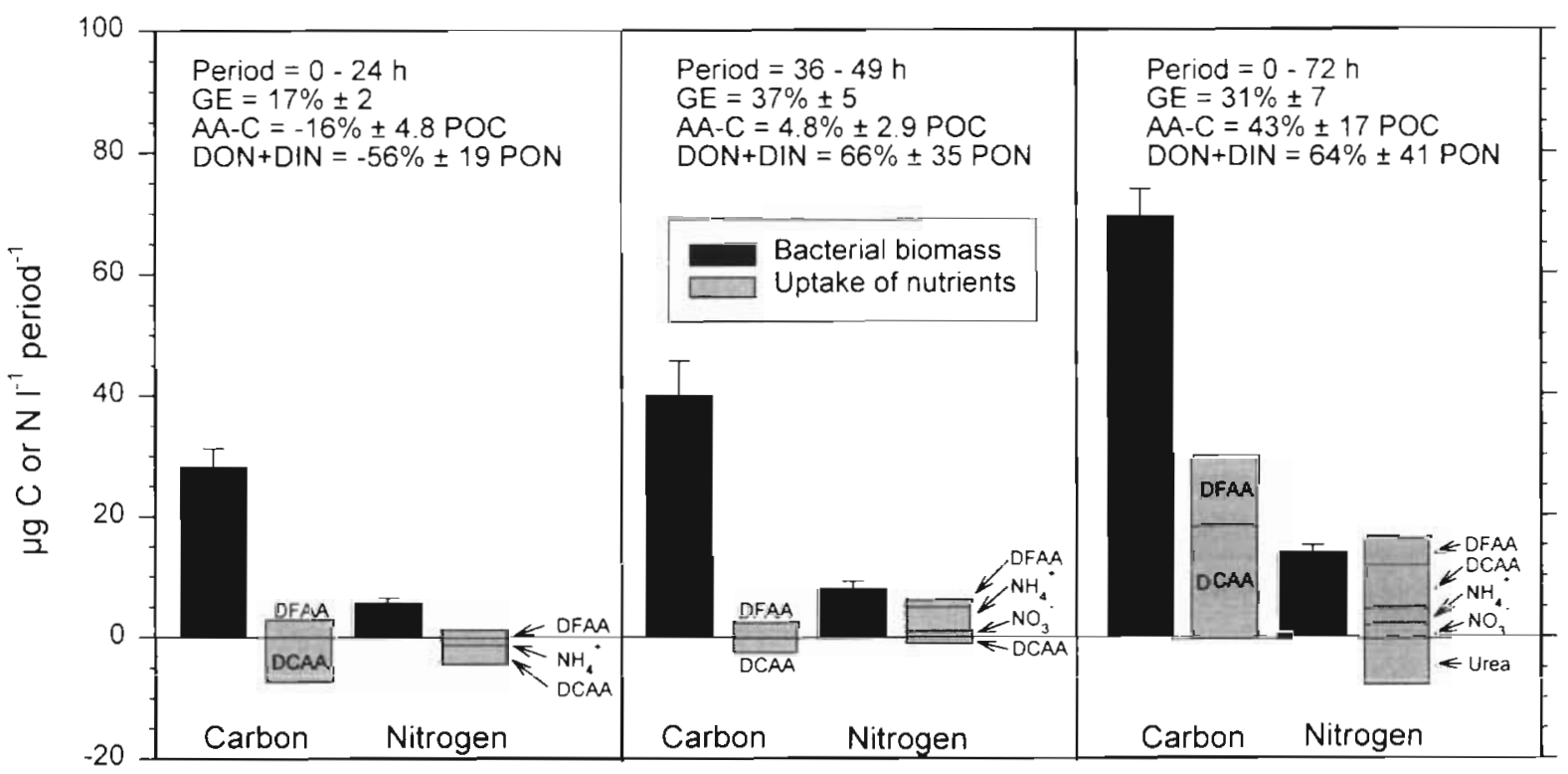

Santa Rosa Sound

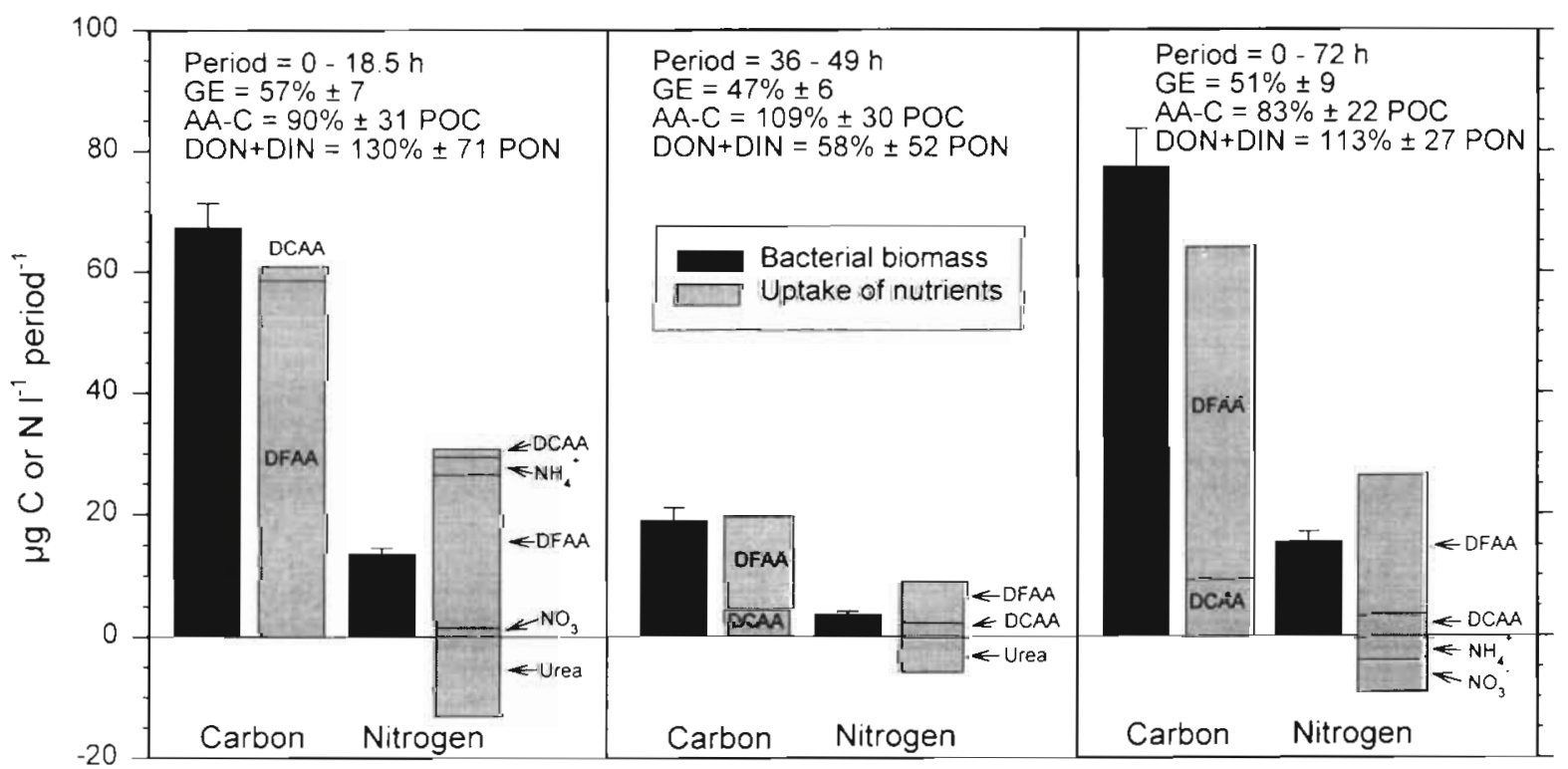

Fig. 3. Bacterial carbon and nitrogen production and mass balances in the GM and SRS cultures during the 2 periods of increasing cell density and the entire $72 \mathrm{~h}$ growth period. Error bars are $\pm 1 \mathrm{SD}$. The bacterial growth efficiency (GE) is calculated from the equation $\mathrm{GE}=\Delta \mathrm{POC} /\left[\mathrm{POC}+\Delta \mathrm{O}_{2}\right.$ (in C equivalents) $] \times 100$. AA-C represents net uptake of DFAA and DCAA relative to production of particulate organic carbon (POC). DON + DIN represents net uptake of dissolved organic nitrogen (DON measured as amino nitrogen) and inorganic nitrogen (DIN, ammonium, nitrate and urea) relative to particulate production of $N$ (PON). Uptake of DFAA was determined from incorporation of ${ }^{14} \mathrm{C}$-amino acids, while uptake or release of DCAA, ammonium, nitrate and urea was determined from changes in concentration between the start and end of the periods. A negative uptake indicates a release

coastal GM location is primarily of phytoplanktonic origin (Kelley et al. 1998). There are seasonal variations in DOC and nutrient concentrations in both environments, but in SRS concentrations are approximately 2 -fold higher than in the GM (Table 2).
The bacterial cultures from the 2 locations differed with respect to $\mathrm{C}$ and $\mathrm{N}$ metabolism, respiration rate and enzyme activity. Relative to the GM cultures, the bacteria in the SRS cultures had a lower respiration rate, a higher uptake of DON (amino acids) than of 

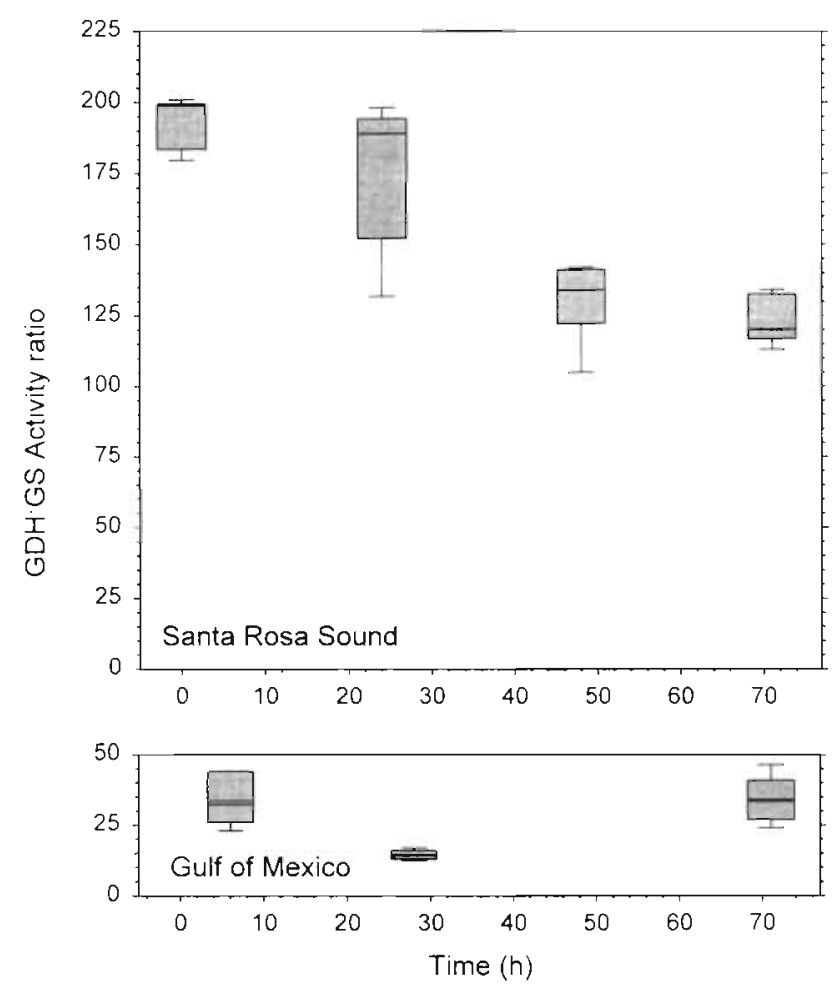

Fig. 4. Relative glutamate dehydrogenase (GDH) and glutamine synthetase (GS) activity in the SRS and GM cultures. Boxplots of 3 cultures (for SRS only 2 cultures were included at 49 and $72 \mathrm{~h}$ due to deviating data). Experimental error is indicated by $95 \%$ percentile values ( $n=9$, triplicates from each of 3 cultures)

DIN, a higher leu-MCA and GDH activity, and a significant release of urea during the 2 analyzed growth periods (Fig. 3, Table 2).

The bacterial growth parameters were studied in 2 separate periods with increasing cell density and related to the total $72 \mathrm{~h}$ incubation period. The reduction of the bacterial density in both cultures after 1 to $1 \frac{1}{2} \mathrm{~d}$ most likely was caused by viral infection, as no bacterial grazers (flagellates) were observed during epifluorescence microscopy of the DAPI-stained bacterial samples. However, we cannot exclude the presence of bactivorous flagellates in the cultures since the volumes filtered for bacterial counts may have been insufficient for detection of flagellates.

\section{$\mathrm{C}$ and $\mathrm{N}$ incorporation}

In the SRS cultures, DFAA, followed by DCAA, were the dominant nitrogen compounds assimilated by the bacteria, except in Period 1 when uptake of ammonium and nitrate exceeded the DCAA uptake. The 2.4to 18-fold higher cell-specific DFAA assimilation in the SRS than in the GM cultures provided together with DCAA sufficient $C$ for the bacterial production. Since the $\mathrm{C} / \mathrm{N}$ ratio of amino acids (C/N of 3.2) is lower than that of typical marine bacteria (C/N of 4 to 7; Tezuka 1990, Kroer 1994), an excess uptake of nitrogen from the amino acids occurred. This overabundance of $\mathrm{N}$ probably led to the observed release of urea in the cultures. Despite of the excess uptake of amino $N$, assimilation of ammonium in the SRS cultures, equivalent to $31 \%$ of the bacterial $N$ production, occurred in Period 1. This suggests that DFAA initially were a source of $C$ rather than $N$ to the SRS bacteria.

In the GM cultures, amino acids were of minor importance as a $\mathrm{N}$ source in Periods 1 and 2, mainly due to a large release of DCAA, which during the initial $24 \mathrm{~h}$ exceeded the DFAA uptake. Instead ammonium and nitrate provided $N$ for the bacterial production. In the entire $72 \mathrm{~h}$ period, a higher uptake of DFAA

Table 2. Typical concentrations of DOC, DIN (ammonium and nitrate) and DIP (dissolved inorganic phosphorus) in Gulf of Mexico (GM) and Santa Rosa Sound (SRS) during the studied periods. Relative growth characteristics (DFAA assimilation, leu-MCA and GDH vs GS activity, DCAA release, respiration and urea release) of the present bacterial cultures are shown. Where differences between the growth periods occur, a characteristic for each period (first/second/total $72 \mathrm{~h}$ ) is given

\begin{tabular}{|c|c|c|c|c|c|c|c|c|c|}
\hline Culture & $\begin{array}{c}D O C \\
(\mu M C)\end{array}$ & $\begin{array}{c}\text { DIN } \\
(\mu \mathrm{M} N)\end{array}$ & $\begin{array}{c}\text { DIP } \\
(\mu \mathrm{M} P)\end{array}$ & $\begin{array}{c}\text { DFAA } \\
\text { assimilation } \\
\text { per cell }\end{array}$ & $\begin{array}{l}\text { Leu-MCA } \\
\text { activity } \\
\text { per cell }\end{array}$ & $\begin{array}{c}\text { GDH vs } \\
\text { GS activity }\end{array}$ & $\begin{array}{l}\text { DCAA } \\
\text { release }\end{array}$ & $\begin{array}{c}\mathrm{O}_{2} \\
\text { consumption } \\
\text { per cell }\end{array}$ & $\begin{array}{l}\text { Urea } \\
\text { release }\end{array}$ \\
\hline GM & $105-236^{\mathrm{a}}$ & $0.3-0.4^{\mathrm{d}}$ & $0.03-0.05^{d}$ & Low & Low & Low & Yes/Yes/No & High & No/No/Yes \\
\hline SRS & $250-360^{b}$ & $1.1-2.2^{a}$ & $0.07-0.19^{\mathrm{a}}$ & High & High & High & No & Low & Yes/Yes/No \\
\hline \multicolumn{10}{|c|}{${ }^{\circledR}$ Coffin \& Cifuentes unpubl. data } \\
\hline \multicolumn{10}{|c|}{${ }^{b}$ Coffin et al. (1993) } \\
\hline \multicolumn{10}{|c|}{${ }^{\mathrm{C}} \mathrm{High}:>5 ;$ low: $<5$. Units: $10^{-18} \mathrm{~mol}$ DFAA bacteria ${ }^{-1} \mathrm{~h}^{-1}$} \\
\hline \multicolumn{10}{|c|}{${ }^{\mathrm{d}} \mathrm{High}:>3 ;$ low: $<3$. Units: $10^{-18} \mathrm{~mol}$ amino acid bacteria ${ }^{-1} \mathrm{~h}^{-1}$} \\
\hline \multirow{2}{*}{\multicolumn{10}{|c|}{${ }^{e}$ High: $>100$; low: $<100$. Units: GDH/GS units $10^{9}$ bacteria $^{-1}$}} \\
\hline & & & & & & & & & \\
\hline \multicolumn{8}{|c|}{ 'Yes: increased concentration; no: uptake or no change } & & \\
\hline
\end{tabular}


and DCAA, as well as ammonium and nitrate, occurred, and a release of urea was observed. The negative $\mathrm{N}$ balance of $-56 \%$ in Period 1 indicates that $\mathrm{N}$ compound(s) not accounted for in this study were used for cell production.

The reduced amino acid uptake in Periods 1 and 2 in the GM cultures also implies that the contribution of amino acid $C$ to the bacterial biomass production was insignificant or negative (from -16 to $4.8 \%$ ). The total amino acid uptake during the $72 \mathrm{~h}$ period, however, indicated a higher amino $\mathrm{C}$ contribution, corresponding to $43 \%$ of the bacterial production. Apparently the bacteria had a changing metabolism, or substrate preference, during the incubation. Alternatively, the activity of different subpopulations in the cultures varied. Interestingiy, aithough periods without actively dividing bacteria (no increase in cell number) were observed, the ongoing DFAA assimilation demonstrates that the bacterial population maintained a high celi activity throughout the incubation.

The relatively low amino acid uptake in the GM cultures, relative to the SRS cultures, indicates that other DOM compounds were assimilated. A likely carbon source could be monosaccharides (Fig. 1). The reduction of monosaccharides in the GM cultures equalled $86 \mu \mathrm{g} \mathrm{C} \mathrm{l}^{-1} 49 \mathrm{~h}^{-1}$. The gross bacterial $\mathrm{C}$ demand was $275 \mathrm{~g} \mathrm{C} \mathrm{l}^{-1}$ in the 2 periods (based on POC production and GEs of 17 and $37 \%$, Fig. 3), implying that monosaccharides might have sustained about $30 \%$ of the total $C$ consumption. The actual bacterial $C$ contribution from monosaccharides may have been higher, depending on the bacterial monosaccharide respiration rate.

The cell-specific uptake of $\mathrm{C}$ and $\mathrm{N}$ compounds over the entire $72 \mathrm{~h}$ period, measured from changes in concentration, may not represent the actual bacterial assimilation. The bacterial growth and utilization of ammonium, nitrate, urea, DCAA and monosaccharides were determined from differences between initial and final densities and concentrations, respectively. This means that during periods of an unchanged or declining bacterial density, the calculated cell-specific nutrient cycling will be inaccurate due to non-dividing, but metabolically active cells, and release of nutrients from dead bacteria, e.g. after a viral infection (Middelboe et al. 1996). Similarly, the present approach underestimated the actual $72 \mathrm{~h}$ bacterial production due to the decline in bacterial density after 1 and $1 \frac{1}{2} \mathrm{~d}$ in the cultures. The cell-specific activity measurements (respiration, DFAA assimilation and leu-MCA activity) of the total $72 \mathrm{~h}$ periods, however, were intermediary or statistically similar to the rates in Periods 1 and 2 . Obviously the reduction in bacterial density did not introduce changes in respiration and amino acid utilization different from those during the periods of increasing cell numbers.
The present nutrient fluxes emphasize that cycling of $\mathrm{C}$ and $\mathrm{N}$ in batch cultures can be dynamic. Consequently, to measure the actual bacterial utilization of nutrients, concentration changes and uptake rates must be observed at frequent intervals, rather than at the start and end of an incubation period. The potential error introduced by a limited sampling frequency can be illustrated by the changes in DCAA and urea in the GM and SRS cultures (Fig. 3). If only an initial and a final concentration measurement of DCAA and urea had been performed, the release of these compounds would not have been detected in the cultures (Fig. 3).

\section{Bacterial preference for ammonium, DFAA and DCAA}

The $\mathrm{N}$ balance of the bacterial cultures from the 2 locations indicates that ammonium and amino acids are among the major bacterial $N$ sources, and that ammonium may be taken up even if there is an excess assimilation of amino N. A significant uptake of both ammonium and DFAA has previously been found in cultures of marine bacteria (Fuhrman 1990, Keil \& Kirchman 1991, Jørgensen et al. 1993). Studies of preference for ammonium or amino acids have shown that addition of DFAA may reduce the ammonium uptake (Fuhrman et al. 1988, Kirchman et al. 1989), while addition of ammonium may diminish uptake of DCAA (Jørgensen et al. 1994). These results suggest that the bacterial preference for $N$ is DFAA > ammonium > DCAA. However, since amino acids are a source of both $\mathrm{N}$ and $\mathrm{C}$, a specific bacterial demand for $\mathrm{C}$ may change this preference. Our observation of an excess $\mathrm{N}$ uptake via DFAA, and a simultaneous uptake of ammonium, probably supports the hypothesis that DFAA uptake may be controlled by a demand for C, as well as for $\mathrm{N}$. In other studies, bacterial uptake of ammonium was stimulated by monosaccharides (Kirchman \& Keil 1990). Monosaccharides may have influenced the present ammonium utilization, although no significant uptake was observed (Fig. 2). In addition to ammonium, an uptake of nitrate was measured in the cultures. It is uncertain if bacterial nitrate assimilation also is stimulated by organic compounds such as monosaccharides.

A positive relation between the occurrence and incorporation of DFAA relative to DCAA (assimilation of DFAA in favor of DCAA when DFAA are abundant) at different locations was described by Kroer et al. (1994). The present SRS data suggest a similar relation: the DCAA/DFAA concentration ratio was approximately 8 and 15 in Periods 1 and 2, while the corresponding DCAA/DFAA uptake ratios were 0.05 and 0.4. A similar calculation was not performed for the 
total incubation period due to large fluctuations of the amino acid concentrations. Our data suggest that uptake of DCAA can be stimulated when DFAA are low, as has been found in other studies (Coffin 1989, Keil \& Kirchman 1993, Rosenstock \& Simon 1993).

The present results on DFAA and ammonium utilization in part support the observation that DFAA uptake is higher than ammonium uptake in estuarine waters, while the uptake pattern is reversed in more oligotrophic conditions (Hoch \& Kirchman 1995). In open waters, labile DOM compounds other than DFAA may provide carbon for bacterial production. The DFAA uptake at the oligotrophic GM station was lower than at the estuarine SRS station (DFAA C equalled 14 and $69 \%$ of the total $72 \mathrm{~h}$ bacterial $\mathrm{C}$ production, respectively). However, in addition to the uptake, a concurrent release of DCAA was measured in Periods 1 and 2 in the GM cultures, leading to a negative net amino acid uptake. Thus, when estimating the significance of DFAA to bacterial production, both uptake and release of amino acids should be considered.

\section{Release of nitrogen}

Ammonium, urea and DCAA were dominant release products in the cultures, but the fluctuating concentrations of these nitrogen compounds indicate that they, besides being release products, also served as nutrient sources to the bacteria. Different nitrogen compounds were released in the 2 sets of cultures. In the GM cultures, ammonium and DCAA (Periods 1 and 2) or urea (total $72 \mathrm{~h}$ period) were released. No amino acids were released in the SRS cultures; instead a release of urea (Periods 1 and 2) or ammonium and nitrate (total $72 \mathrm{~h}$ period) was measured. A loss of $\mathrm{N}$ was not expected in the GM cultures, which had a negative (Period 1) or insignificant amino acid uptake (Period 2) relative to biomass production (Fig. 3). A possible explanation for the observed ammonium release may be mineralization of DOM substances other than amino acids with a $\mathrm{C} / \mathrm{N}$ ratio below that of bacterial biomass. The processes leading to release of DCAA in the cultures are uncertain, but production of DCAA has previously been observed in cultures of active pelagic bacteria (Jørgensen et al. 1993, 1994, Rosenstock \& Simon 1993, Kroer et al. 1994).

Production of DCAA (including proteins) may be related to the metabolic activity of the bacteria. During starvation, 2 marine bacterial strains have been found to excrete proteases (Albertson et al. 1990). After uptake of protein amino acids (methylated ribulose 1,5-bisphosphate carboxylase), Keil \& Kirchman (1992) observed a production of low-molecular material $(<10 \mathrm{kDa})$, most likely amino acids. Similar production of amino acids from DCAA previously taken up would not have necessarily been registered in our experiments, as uptake or release of DCAA was determined from changes in concentration. Commonly found proteins in seawater are 37 and $48 \mathrm{kDa}$ molecules, of which the latter has homologies to the rather proteaseresistant bacterial membrane protein porin (Tanoue et al. 1996). Thus, constituents of bacterial cells probably make up a portion of the DCAA pool. The DCAA may also represent synthesis of extracellular enzymes (proteins) for the degradation of polymer DOM. Since the DCAA release was observed in the GM cultures in which a rather low-labile DOM pool was present (indicated by a reduced GDH:GS enzyme ratio), a high production of extracellular enzymes could have occurred in these cultures.

In the SRS cultures, release of urea equalled or exceeded the total bacterial $\mathrm{N}$ incorporation. Urea has previously been found to be a major intermediate in ammonification in anoxic marine sediments, especially during periods of high mineralization rates (Pedersen et al. 1993, Therkildsen \& Lomstein 1994, Therkildsen et al. 1996). Recently, however, urea production in oxic cultures of marine bacterioplankton and by pure cultures of 2 marine bacteria has been observed (Cho et al. 1996, Therkildsen et al. 1997).

The biochemical pathways for bacterial urea production involve the enzyme arginase (for degradation of arginine), or more complex enzyme reactions for the degradation of purines (Moran et al. 1994). Usually urea formation is a process for removal of excess $N$, e.g. to reduce the intracellular ammonium pool. In recent studies, natural estuarine bacterioplankton was found to produce urea when grown in seawater enriched with glucose and ammonium, or amino acids, and when the bacteria in long-term batch cultures were deprived of nutrients (Jørgensen unpubl. data). Mortality-related production of urea in the GM cultures might explain the urea increase between 24 and $32 \mathrm{~h}$ as this occurred simultaneous with the drop in the bacterial density. However, during the rest of the incubation period of the GM cultures, as well as in the SRS cultures, the increase of urea coincided with periods of actively growing cells. Our results suggest that bacterial activity can be important in the regulation of ambient urea pools, but they also stress that more studies in bacterial nitrogen metabolism are required to understand the function of urea in the bacterial nutrient cycling.

Exclusion of urea release in the GM and SRS nitrogen budgets would have led to a substantial overestimation of the bacterial $\mathrm{N}$ incorporation (Fig. 3). Previous culture studies of pelagic bacteria, in which analysis of urea was not included, have demonstrated an apparent excess $\mathrm{N}$ incorporation (Keil \& Kirchman 
1991, Jørgensen et al. 1993, 1994, Rosenstock \& Simon 1993, Kroer et al. 1994). It is likely that release of urea, and possibly other $\mathrm{N}$ compounds, caused imbalanced $\mathrm{N}$ budgets in these studies.

\section{Respiration}

Except for a $50 \%$ reduction in Period 2 in the SRS cultures, the cell-specific respiration rate did not vary during the entire incubation period in the 2 sets of cultures, but the rate was 2- to 4 -fold higher in the GM cultures than in the SRS cultures (Table 1). The decline in the SRS cultures between 36 and $49 \mathrm{~h}$ coincided with increased concentrations of DFAA and DCAA, and a reduced leu-MCA activity. These changes may indicate a shift in metabolic processes of the bacteria, e.g. due to variations in the population structure.

The higher cell-specific respiration in the GM than in the SRS cultures was reflected in lower growth efficiencies in GM (17 to $37 \%$ ) than in SRS ( 47 to $57 \%$ ). Reported bacterial GEs in offshore Gulf of Mexico waters are variable, with values frequently ranging from below $10 \%$ (Pomeroy et al. 1995) to 25-61\% during periods with high production (Kroer 1993, Amon \& Benner 1994). In SRS, GEs of 1 to $35 \%$ have been reported (Coffin et al. 1993, Kroer 1993, Jørgensen et al. 1994). Coffin \& Connolly (1997) observed that the growth rate of bacteria, at least over short time scales, represents a balance between the ecosystem carrying capacity (with regard to nutrient and carbon availability) and predation from higher trophic levels. With predation on bacteria, microzooplankton mineralize nutrients. Through this cycle it is expected that the availability of nutrients controls the GE of the bacteria. The difference in GE that was observed between SRS and the coastal GM is likely to be a function of nutrient cycling. The higher amino acid uptake in the SRS than the GM cuitures as well as the difference in activity of enzymes involved in the bacterial $\mathrm{N}$ assimilation (discussed below) both support the fact that more labile $\mathrm{N}$ was available in SRS than in GM.

\section{Enzyme activity}

Differences in the activity of the GDH and GS enzymes suggest that nitrogen did not limit the bacterial production in the SRS cultures, while nitrogen could be a controlling factor in the GM cultures. The GDH activity was 5- to 10-fold higher in the SRS cultures than in the GM cultures, while the GS activity was rather similar at the 2 stations. GDH is used to provide nitrogen (from intracellular ammonium) for biosynthetic purposes when the ammonium level is high, while the GS and glutamate synthetase (GOGAT) cycle is active at low intracellular ammonium concentrations

The high GDH activity in the SRS cultures suggests that more labile nitrogen was available to the bacteria in the SRS than in the GM cultures, e.g. due to production of ammonium from degradation of organic matter. Because the activity of the GS and GOGAT enzymes requires $A T P$ and $N A D(P) H$, we suggest that the lower growth efficiency of the GM bacteria in part could have been due to a reduced availability of labile nitrogen, which forced the bacteria to spend energy on production of ATP and NAD(P)H.

The cell-specific aminopeptidase activity changed during the incubation. The activity either stabilized after initial fluctuations (GM) or decreased during most of the incubation (SRS). These variations may be caused by changes in the available nutrient pools, or by changing metabolic requirements. Fluctuations of the DCAA pool demonstrate that DCAA were produced and taken up during the incubations. The reduced or declining leu-MCA activity during the end of the incubation periods may indicate that most of the biologically available DCAA fraction already was exhausted.

The integrated leu-MCA activity was 2.5- to 2.7-fold higher in the SRS than in the GM cultures (Table 1). We believe that this difference illustrates a higher abundance of labile DOM in the SRS estuary than in the open-water GM station. In support of this, an increased leu-MCA activity has been observed along an oligotrophic $\rightarrow$ eutrophic gradient in the Adriatic Sea (Karner et al. 1992). The measured leu-MCA activity in our study was used to trace the turnover of the ambient DCAA pools. However, the measured activity probably did not represent the actual aminopeptidase activity, as (1) the added leu-MCA concentration was not added at a tracer level, but was 3 - to 4 -fold higher than the DCAA pool; (2) other amino acids than leucine were abundant in the DCAA; and (3) although proteins are abundant in seawater (Tanoue et al. 1996), all DCAA were probably not available for biological degradation (Keil \& Kirchman 1993).

Leu-MCA and similar substrate analogs have been used as measures or indicators of biological degradation of many polymers (Chróst 1991), but the measured enzyme activity has generally not been related to actual changes in the substrate concentration. In the present study, a release of DCAA was measured in 2 (GM Periods 1 and 2) of the 6 periods studied, although a positive leu-MCA activity always was measured in both sets of cultures. Apparently a positive aminopeptidase activity can be measured, in spite of a significant release - and net loss - of proteins. This has been confirmed in studies of intact estuarine water (Middelboe 
et al. 1998). Probably the exoenzyme production and cellular release are independent processes, although interrelated, as the produced enzymes contribute to the extracellular DCAA pool. Our results emphasize that substrate analog activities should be used with great caution.

\section{Bacterial production versus trophic level}

The present results demonstrate that, despite differences in metabolic processes and $\mathrm{N}$ assimilation, the observed biomass production at the 2 locations was comparable: the POC accumulation was 68 and $87 \mu \mathrm{g}$ $\mathrm{C}^{-1}$ in the GM and SRS cultures, respectively, corresponding to a $22 \%$ higher production in SRS $(p<0.05)$. The bacterial production in the SRS cultures falls within, or is slightly lower than, the biomass accumulation previously measured in cultures from this estuary (Jørgensen et al. 1993, 1994, Kroer et al. 1994).

The rather similar production in the GM and SRS cultures stresses that an open-water ecosystem can support bacterial production similar to that of an estuarine environment. However, the bacterial growth occurred at a high expense of DOC. Production of $1 \mathrm{\mu g}$ bacterial $C$ in the GM cultures required $4.0 \mu \mathrm{g} \mathrm{DOC}$ during the $72 \mathrm{~h}$ growth period, compared to only $1.8 \mathrm{\mu g}$ DOC in SRS cultures. Since the 2 bacterial communities had different nitrogen metabolism, we postulate that the quality and quantity of nitrogen available to the bacteria was a main factor in regulating the bacterial growth efficiency in the 2 cultures. High bacterial production at a low growth efficiency and with inorganic $N$ as the main nitrogen source previously has been observed in oceanic waters (Kirchman et al. 1991). Thus, the actual availability of $\mathrm{N}$ and $\mathrm{C}$, rather than the trophic level as such, may determine the potential for bacterial growth.

The present cycling of $\mathrm{N}$ by bacteria from the 2 locations suggests that microorganisms in estuarine environments may be direct producers of DIN (from mineralization of DON), and hence support phototrophic plankton production, while bacteria in more oligotrophic waters may compete with the phototrophic organisms for available DIN. The reduced carbon conversion efficiency observed in the GM cultures has implications for the microbial loop, as less biomass will be available to bacterivory-based food chains. Another consequence of the low channeling of $\mathrm{C}$ into bacterial biomass is that in relatively oligotrophic environments lower biological production is maintained and thus the system will tend to remain oligotrophic. It must be remembered, however, that since aquatic environments are dynamic ecosystems with respect to cycling of organic and inorganic nutrients, there probably will be periods in which discrepancies in microbial activity, similar to the presently observed differences between the GM and SRS, will be less distinct, despite a difference in trophic level.

Acknowledgements. We wish to thank R. E. Jensen, K. Dillon, J. Campbell and the crew of the OSV 'Peter W. Andersen' for technical assistance. J. Pakulski and $W$. Jeffrey kindly provided assistance and materials for analysis of saccharides. The study was supported by grants from NATO Scientific Affairs Division (CRG 900536 to N.O.G.J.), The Danish Strategic Environmental Research Program (to N.O.G.J. and N.K.) and The Danish Natural Science Research Council.

\section{LITERATURE CITED}

Ahmed SI, Kenner RA, Packard TT (1977) A comparative study of the glutamate dehydrogenase activity in several species of marine phytoplankton. Mar Biol 39:93-101

Albertson NH, Nyström T, Kjelleberg S (1990) Exoprotease activity of two marine bacteria during starvation. Appl Environ Microbiol 56:218-223

Amon RMW, Benner R (1994) Rapid cycling of high-molecular weight matter in the ocean. Nature 369:549-552

Bender RA, Janssen KA, Resnick AD, Blumenberg M, Foor F, Magasanik B (1977) Biochemical parameters of glutamine synthetase from Klebsiella aerogenes. J Bacteriol 129: $1001-1009$

Billen G, Joiris C, Wijnant J (1980) Concentration and microbiological utilization of small organic molecules in the Scheldt Estuary, the Belgian coastal zone of the North Sea and the English Channel. Estuar Coast Mar Sci 11. $279-294$

Carlson CA, Ducklow HW (1996) Growth of bacterioplankton and consumption of dissolved organic carbon in the Sargasso Sea. Aquat Microb Ecol 10:69-85

Cherrier J, Bauer JE, Druffel ERM (1996) Utilization and turnover of labile dissolved organic matter by bacterial heterotrophs in eastern North Pacific surface waters. Mar Ecol Prog Ser 139:267-279

Cho BC, Park MG, Shim JH, Azam F (1996) Significance of bacteria in urea dynamics in coastal surface waters. Mar Ecol Prog Ser 142:19-26

Chróst RJ (1991) Environmental control of the synthesis and activity of aquatic microbial ectoenzymes. In: Wetzel RG, Chróst RJ, Münster U, Billen G, Jacobsen TR, Rai H (eds) Microbial enzymes in aquatic environments, SpringerVerlag, London, p 29-59

Coffin RB (1989) Bacterial uptake of dissolved free and combined amino acids in estuarine waters. Limnol Oceanogr $34: 531-542$

Coffin RB, Connolly JP (1997) Bacterial and heterotrophic microflagellate production in the Santa Rosa Sound, Florida. Hydrobiologia 353:53-61

Coffin RB, Velinsky D, Devereux R, Price WA, Cifuentes LA (1990) Stable carbon isotope analysis of nucleic acids to trace sources of dissolved substrate used by estuarine bacteria. Appl Environ Microbiol 56:2012-2020

Coffin RB, Connolly JP, Harris PS (1993) Availability of dissolved organic carbon to bacterioplankton examined by oxygen utilization. Mar Ecol Prog Ser 101:9-22

Cotner JB, Peele ER, Ammerman JW, Bentzen E (1994) Phosphorus-limited plankton growth in the Sargasso Sea 
(BATS) and its implications of the pelagic food web. EOS $75: 75$

del Giorgio PA, Scarborough G (1995) Increase in the proportion of metabolically active bacteria along gradients of enrichment in freshwater and marine plankton: implications for estimates of bacterial growth and production rates. J Plankton Res 17:1925-1938

Fuhrman $J$ (1990) Dissolved free amino acid cycling in an estuarine outflow plume. Mar Ecol Prog Ser 66:197-203

Fuhrman JA, Horrigan SH, Capone DG $(1988)$ Use of ${ }^{13} \mathrm{~N}$ tracer for bacterial and algal uptake of ammonium from seawater. Mar Ecol Prog Ser 45:271-278

Guo L, Santschi PH, Cifuentes LA, Trumbore SE, Southon J (1996) Cycling of high-molecular-weight dissolved organic matter in the Middle Atlantic Bight as revealed by carbon isotopic $\left({ }^{13} \mathrm{C}\right.$ and $\left.{ }^{14} \mathrm{C}\right)$ signatures. Limnol Oceanogr 41:1242-1252

Happ G, Gosselink JG, Day JW Jr (1977) The seasonal distribution of organic carbon in a Lonisiana estuary. Estuar Coast Mar Sci 5:695-705

Hoch MP, Kirchman DL (1995) Ammonium uptake by heterotrophic bacteria in the Delaware estuary and adjacent coastal waters. Limnol Oceanogr 40:886-897

Jahnke RA, Craven DB (1995) Quantifying the role of heterotrophic bacteria in the carbon cycle: a need for respiration rate measurements. Limnol Oceanogr 40:436-441

Johnson KM, Sieburth JMcN (1977) Dissolved carbohydrates in seawater. I. A precise spectrophotometric analysis for monosaccharides. Mar Chem 5:1-13

Jørgensen NOG, Jensen RE (1997) Determination of dissolved combined amino acids using microwave-assisted hydrolysis and HPLC precolumn derivatization for labeling of primary and secondary amines. Mar Chem 57:287-297

Jørgensen NOG, Kroer N, Coffin RB, Yang XH, Lee C (1993) Dissolved free amino acids, combined amino acids, and DNA as sources of carbon and nitrogen to marine bacteria. Mar Ecol Prog Ser 9:135-148

Jørgensen NOG, Kroer N, Coffin RB (1994) Utilization of dissolved nitrogen by heterotrophic bacterioplankton: effects of substrate C/N ratio. Appl Environ Microbiol 60:4124-4133

Karner M, Fuks D, Herndl GJ (1992) Bacterial activity along a trophic gradient. Microb Ecol 24:243-257

Keil RG, Kirchman DL (1991) Contribution of dissolved free amino acids and ammonium to the nitrogen requirements of heterotrophic bacterioplankton. Mar Ecol Prog Ser 73:1-10

Keil RG, Kirchman DL (1992) Bacterial hydrolysis of protein and methylated protein and its implications for studies of protein degradation in aquatic systems. Appl Environ Microbiol 58:1374-1375

Keil RG, Kirchman DL (1993) Dissolved combined amino acids: chemical form and utilization by marine bacteria. Limnol Oceanogr 38:1256-1270

Kelley CA, Coffin RB, Cifuentes LA (1998) Stable isotope evidence for alternative bacterial carbon sources in the Gulf of Mexico. Limnol Oceanogr 43:1962-1969

Kirchman DL, Keil RG (1990) Carbon limitation of ammonium uptake by heterotrophic bacteria in the subarctic Pacific Limnol Oceanogr 35:1258-1266

Kirchman DL, Keil RG. Wheeler PA (1989) The effect of amino acids on ammonium utilization and regeneration by heterotrophic bacteria in the subarctic Pacific. Deep-Sea Res $36: 1763-1776$

Kirchman DL, Suzuki Y, Garside C, Ducklow HW (1991) High turnover rates of dissolved organic carbon during a spring phytoplankton bloom. Nature 352:612-614

Kroer N (1993) Bacterial growth efficiency on natural dissolved organic matter. Limnol Oceanogr 38:1282-1290
Kroer N (1994) Relationships between biovolume and carbon and nitrogen content of bacterioplankton. FEMS Microbiol Ecol 13:217-224

Kroer N, Jargensen NOG, Coffin RB (1994) Utilization of dissolved nitrogen by heterotrophic bacterioplankton. A cross ecosystem analysis. Appl Environ Microbiol 60:4116-4123

Lindroth P, Mopper K (1979) High performance liquid chromatographic determinations of subpicomole amounts of amino acids by precolumn fluorescence derivatization with o-phthaldialdehyde. Anal Chem 51:1667-1674

Lohrenz SE, Dagg MJ, Whitledge TE (1990) Enhanced primary production at the plume/oceanic interface of the Mississippi River. Cont Shelf Res 7:639-664

Middelboe M, Nielsen B, Sondergaard M (1992) Bacterial utilization of dissolved organic carbon (DOC) in coastal waters-determination of growth yield. Arch Hydrobiol Beih Ergebn Limnol 37:51-61

Middelboe M, Borch NH, Kirchman DL (1995) Bacterial utilization of dissolved free amino acids, dissolved combined amino acids and ammonium in the Delaware Bay estuary: effects of carbon and nitrogen limitation. Mar Ecol Prog Ser 128:109-120

Middeiboe ivi, Jorgensen NOG, Kroer $N$ (1996) Eftects of viruses on nutrient turnover and growth efficiency of noninfected marine bacterioplankton. Appl Environ Microbiol 62:1991-1997

Middelboe M, Kroer N, Jørgensen NOG, Pakulski J (1998) The influence of sediment on pelagic carbon and nitrogen turnover in a shallow Danish estuary. Aquat Microb Ecol $14: 81-90$

Moran LA, Scrimgeour KG, Horton HR, Ochs RS, Rawn JD (1994) Biochemistry. Prentice Hail, Englewood Cliffs, NJ

Mulvenna PF, Savidge G (1992) A modified manual method for the determination of urea in seawater using diacetylmonoxime reagent. Estuar Coast Shelf Sci 34:429-438

Pakulski JD, Benner R (1992) An improved method for the hydrolysis and MBTH analysis of dissolved and particulate carbohydrates in seawater. Mar Chem 40:143-160

Pedersen H, Lomstein BA, Blackburn TH (1993) Evidence for bacterial urea production in marine sediments. FEMS Microbiol Ecol 12:51-59

Pomeroy LR, Sheldon JE, Sheldon WM, Peters F (1995) Limits to growth and respiration of bacterioplankton in the Gulf of Mexico. Mar Ecol Prog Ser 117:259-268

Porter KG, Feig YS (1980) The use of DA.PI for identifying and counting aquatic microflora. Limnol Oceanogr 25:943-948

Price NM, Harrison PJ (1987) Comparison of methods for the analysis of dissolved urea in seawater. Mar Biol 94 $307-317$

Rich JH, Ducklow HW, Kirchman DL (1996) Concentration and uptake of neutral monosaccarides along $140^{\circ} \mathrm{W}$ in the equatorial Pacific: contribution of glucose to heterotrophic bacterial activity and the DOM flux. Limnol Oceanogr 41: 595-604

Rosenstock B. Simon M (1993) Use of dissolved combined and free amino acids by planktonic bacteria in Lake Constance. Limnol Oceanogr 38:1521-1531

Shapiro BM. Stadtman ER (1970) Glutamine synthetase ( $E$. coli). Methods Enzymol 17A:910-922

Søndergaard M, Middelboe M (1995) A cross-system analysis of labile dissolved organic carbon. Mar. Ecol Prog Ser 118: $283-294$

Tanoue E, Ishii M, Midorikawa T (1996) Discrete dissolved and particulate proteins in oceanic waters. Limnol Oceanogr 41:1334-1343

Tezuka Y (1990) Bacterial regeneration of ammonium and as affected by the carbon:nitrogen:phosphorus ratio of 
organic substrates. Microb Ecol 19:227-238

Therkildsen MS, Lomstein BA (1994) Seasonal variation in sediment urea turnover in a shallow estuary. Mar Ecol Prog Ser 109:77-82

Therkildsen MS, King GM, Lomstein BA (1996) Urea production and turnover following the addition of AMP, CMP RNA and a protein mixture to a marine sediment. Aquat Microb Ecol 10:173-179

Therkildsen M.S, Isaksen MF, Lomstein BA (1997) Urea pro-

Editorial responsibility: Patricia Glibert, Cambridge, Maryland, USA duction by the marine bacteria Delaya venusta and Pseudomonas stutzen grown in a minimal medium. Aquat Microb Ecol 13:213-217

Zweifel UL, Norrman B, Hagström \& (1993) Consumption of dissolved organic carbon by marine bacteria and demand for inorganic nutrients. Mar Ecol Prog Ser 101:23-32

Zweifel UL, Wikner J, Hagström $\AA$, Lundberg E, Norrman B (1995) Dynamics of dissolved organic carbon in a coastal ecosystem. Limnol Oceanogr 40;299-305

Submitted: June 6, 1998; Accepted: January 7, 1999 Proofs received from author(s): August 5, 1999 